\title{
Kingship, sexuality and courtly masculinity: Frederick the Great and Prussia on the cusp of modernity ${ }^{1}$
}

Bodie A Ashton

University of Passau

Abstract: The discovery in 2011 of an erotic poem written by Frederick the Great reignited popular interest in the debate concerning Frederick's sexual being. Seemingly depicting a male-male tryst, the poem failed to end this undecided speculation. It did, however, reopen questions about how scholars have remembered and constructed Frederick's gender and sexuality. This article demonstrates that these questions have been predicated upon incorrect assumptions regarding how the early modern Prussian state and society conceived of their monarch. While it is commonly argued that sex was considered a function of gender-thus marking same-sex-desiring men as 'feminine'- the very concept of masculinity was governed by social cues and cultural expectations that extended far beyond sexual desire. As is argued in this analysis, Frederick's assumed homosexuality had no bearing on his kingship; by his behaviour and public conduct he remained the epitome and embodiment of Prussian masculinity.

The recent discovery in Berlin of a poem briefly reignited a long-running debate as to the sexual identity of the Prussian King Frederick II, better known by his sobriquet 'Frederick the Great'. The poem, apparently describing a male-male tryst involving the king and one of his closest friends, made headlines around the world, declaring that evidence had been found that Frederick was homosexual. The impulsive response, however, masked the deeper complexities of the issue.

1 The author is indebted to his (mostly) willing readers and audiences, particularly Robin Prior, Gareth Pritchard, Matilda Handsley-Davis and Tamika Glouftsis of the University of Adelaide, and Matthew P Fitzpatrick at Flinders University. Finally, thanks must go to the members of the University of Adelaide's informal 'Priory Group' for their considered input. 
Using the debate concerning Frederick's sexual identity as its starting point, this article aims to re-evaluate the king's character through the prism of Prussian gender norms and ideals. It argues that Frederick the Great reigned not as an aberration but as a paragon of Prussian masculine virtue, a claim that was not in any significant way impinged on, or impeded by, his assumed same-sex desires. This argument is based on four key premises. First, Frederick either had conspicuous same-sex desires, or else he 'coded' or 'presented' as though he did. This was widely identified by his contemporaries and has since become a preoccupation among Frederick's biographers. Second, Frederick's apparent same-sex desires, while contrary to the letter of the law as well as conceptions of masculinity that developed among the Prussian bourgeoisie of the nineteenth century, were hardly unusual for the time, and fit within the rubric of an Enlightenment sensibility that was particularly-if not uniquelyGerman. Third, though same-sex acts were ostensibly regulated by law in a draconian fashion, this did not necessarily subvert a man's gender; a man could, in other words, feel and express same-sex desire while still being a man. Finally, the construction of masculinity within the Prussian state in the early modern period was a complex and multifaceted process that relied largely upon social and cultural cues set out in contemporaneous 'manuals of masculinity', known as the Hausväterliteratur, rather than biology and sex. In the final analysis, the Prussian king was expected to be the paragon of Prussian masculine virtue who followed the guiding principles of Prussian noble masculinity. Frederick the Great's character as a sensitive romantic with (at the very least) homoerotic artistic tendencies did nothing to disqualify him from this role; in fact, the very characteristics that, from the nineteenth century to today, have marked him as being an outlier who practised 'feminine' caprice, actually confirmed and consolidated his position as a virtuous Prussian man.

\section{La Jouissance and the historiography of Frederick's sexuality}

In 2011 a previously unknown poem, written by Frederick the Great, was discovered in a Berlin archive. Frederick was a prolific poet, though the reception of this body of work had been mixed. Voltaire, who enjoyed correspondence with the philosopher-king before going to live with him in Potsdam in 1752, had often chided him on his occasionally clumsy French transitions, while Thomas Babington Macaulay-admittedly 
not a sympathetic biographer-had dismissed his verses as vulgar and turgid. ${ }^{2}$ Thomas Carlyle, on the other hand, thought Frederick's attempts had significant artistic merit. Frederick himself, in a letter to the French philosopher Jean-Baptiste d'Alembert, dismissed his own poetry as the work of a 'dilettante' while d'Alembert's work would endure in artistic immortality; his one hope was that his work was lyrical enough to send d'Alembert to sleep. ${ }^{3}$ In another earlier letter to Voltaire, Frederick wrote:

Do not, at least, suppose that I write in verse purposely to enter the lists with you. I stammering answer in a language which Voltaire and the Gods only are allowed to speak. ${ }^{4}$

Yet it was neither the existence nor quality of the poem that caused excitement, so much as its content. Written shortly after Frederick had ascended to the Prussian throne in 1740, it was addressed to Frederick's friend and courtier, the diplomat and libertine Count Francesco Algarotti (here addressed by the affectionate nickname, 'Swan of Padua'). Entitled La Jouissance-The Pleasure, or more accurately, The Orgasm — the poem is an exercise in eighteenth-century erotic verse. One of Frederick's biographers, the historian Giles MacDonogh, provided a translation for the History Today website shortly after the original text was published in full in the German newspaper Die Zeit.

This night, vigorous desire in full measure,

Algarotti wallowed in a sea of pleasure.

A body not even a Praxitiles fashions

Redoubled his senses and imbued his passions

Everything that speaks to eyes and touches hearts,

Was found in the fond object that enflamed his parts.

Transported by love and trembling with excitement

In Cloris' arms he yields himself to contentment

The love that unites them heated their embraces

And tied bodies and arms as tightly as laces.

Divine sensual pleasure! To the world a king!

Mother of their delights, an unstaunchable spring,

Speak through my verses, lend me your voice and tenses

2 Thomas Babington Macaulay, Life of Frederick the Great (New York: The Useful Knowledge Publishing Company, 1882), 18-19.

3 George Peabody Gooch, 'Old Age', in Frederick the Great: A Profile, ed. Peter Paret (New York: Hill \& Wang, 1972), 45: doi.org/10.1007/978-1-349-01476-7_3.

4 Frederick II to Voltaire, Remusburg, 30 September 1738, in Letters between Frederic II. and M. de Voltaire, ed. Thomas Holcroft (London: GGJ and J Johnson, 1789), 412-13. 
Tell of their fire, acts, the ecstasy of their senses!

Our fortunate lovers, transported high above

Know only themselves in the fury of love:

Kissing, enjoying, feeling, sighing and dying

Reviving, kissing, then back to pleasure flying.

And in Knidos' grove, breathless and worn out

Was these lovers' happy destiny, without doubt.

But all joy is finite; in the morning ends the bout.

Fortunate the man whose mind was never the prey

To luxury, or grand airs, one who knows how to say

A moment of climax for a fortunate lover

Is worth so many aeons of star-spangled honour. ${ }^{5}$

Upon its translation, the poem caused some excitement. Different versions of the story of its discovery and content appeared in news outlets, both in print and online. ${ }^{6}$ Some of the excitement was stoked by MacDonogh himself, who speculated that the poem may be Frederick's firsthand account of a sexual tryst he had experienced with Algarotti. Indeed, the relationship between the two has been a matter of some debate for centuries and, though MacDonogh's own 1999 biography of Frederick had taken an ambiguous stance on the question of Frederick's sexuality, La Jouissance appears to have convinced him that Frederick was gay. ${ }^{7}$

Yet, for all this, the poem did little to alter the terms of the scholarly historical debate. The explicit sexuality of the poem piqued the interest of the public, most of whom were unfamiliar with the extant literature surrounding the king, but Frederick's poems number in the hundreds, and many-including erotic pieces-were addressed to the Swan of Padua, Francesco Algarotti. If Frederick's existing homoerotic poems had not yet convinced the academy as to whether or not the king had same-sex desires, this new discovery—whatever its content—was unlikely to do so.

5 Cited in Kathryn Hadley, 'Frederick the Great's Erotic Poem', History Today, 21 September 2011, accessed at www.historytoday.com/blog/2011/09/frederick-greats-erotic-poem.

6 For example, Vanessa de Senarclens, 'Friedrichs Schoßgebet', Die Zeit, 18 September 2011, accessed at www.zeit.de/2011/38/Schossgebet; Matthew Day, 'Frederick the Great-The Erotic Poet', Telegraph, 15 September 2011, accessed at www.telegraph.co.uk/news/worldnews/europe/germany/8764799/ Frederick-the-Great-the-erotic-poet.html; 'Prussian King Frederick the Great's Erotic Poem Found', BBC News, 16 September 2011, accessed at www.bbc.com/news/world-europe-14945573; John Lundberg, 'Frederick the Great's Erotic Poem', Huffington Post, 18 September 2011, accessed at www. huffingtonpost.com/john-lundberg/frederick-the-great-poems_b_966460.html.

7 Giles MacDonogh, Frederick the Great: A Life in Deed and Letters (New York: St Martin's Press, 1999), 221-23. 
The La Jouissance affair may have been a damp squib, but it also demonstrates that Frederick the Great's sexuality remains a topic of contention more than two centuries after his death. In general, the modern historiography concerning Frederick is either preoccupied with this aspect of his identity, or else (and just as conspicuously) preoccupied with avoiding it, with attention waxing and waning seemingly at random across the decades. Nancy Mitford, for example, was convinced of Frederick's homosexuality but professed not to understand it. The solution, as she saw it, was to ignore it. ${ }^{8}$ David Fraser views the suggestions of homosexuality as little more than 'imputations' that were spread by Frederick's enemies, probably as a result of his childless marriage, and dismisses the numerous reported instances of Frederick's same-sex desire as 'the varied inclinations of a cultivated sophisticate with a taste for bawdiness, or, later, the fumblings of a lonely old man'. 'Theodor Schieder takes a similar line, seeing any discussion of Frederick's male-male desires as 'malicious' and ascribing them to the (unsubstantiated) claim that Frederick was sterile. ${ }^{10}$

Gerhard Ritter's biography, for many years considered the most complete (if short) modern account of Frederick's life, skirts the issue with selfconscious blushes; in this text, the two men most often identified as Frederick's lovers-Hans Hermann von Katte and Algarotti—are reduced to mere footnotes, mentioned almost as an afterthought as a 'friend' and a 'braggart' respectively. ${ }^{11}$ MacDonogh's biography, as has been noted, takes a rather ambivalent line on the question, but still contains no fewer than 12 index entries relating to Frederick's sexuality. Frederick's most recent biographer, Tim Blanning, sees Frederick's circle of intimates as 'homosocial and homoerotic and, for Frederick himself, probably homosexual too'. In Blanning's account, Algarotti is credited with reawakening Frederick's 'sexual liberation'. ${ }^{12}$

8 Kate Williams, 'Introduction', in Nancy Mitford, Frederick the Great (London: Vintage, 2011), xvii. Mitford's 'ignorance' of Frederick's sexuality notwithstanding, there are a number of veiled references to it. So, for instance, Frederick's youthful friendship with Keith and Katte was 'extremely debauched', and Frederick William I 'had suspicions about the relationship' between Frederick and Katte. Later, Mitford abandons all pretext whatsoever, and declares that Frederick fell in love with Algarotti, who had 'confirmed in him an already latent homosexuality'. Mitford, Frederick the Great, $22,25 \& 52$.

9 David Fraser, Frederick the Great: King of Prussia (London: Penguin, 2000), 39-41.

10 Theodor Schieder, Frederick the Great (Harlow: Pearson, 2000), 40-41.

11 Gerhard Ritter, Frederick the Great: An Historical Profile (London: Eyre \& Spottiswoode, 1968), $30-31 \& 42$.

12 Tim Blanning, Frederick the Great: King of Prussia (London: Allen Lane, 2015), xxiii \& 64. 
Even during Frederick's lifetime, his sexual proclivities were subject to rumour. A measure of how widespread such suspicions were can be seen in the reflections written by Frederick's personal physician, Johann Georg Zimmermann, upon Frederick's death in 1786. Zimmermann denied that Frederick's sexual tastes extended to men, but admitted that this was the common belief among the courts and societies of Europe:

innumerable Frenchmen and Germans, almost all the friends and enemies of Frederick, almost all the princes and great men of Europe, even his servants - even the confidants and friends of his later years, were of the opinion that he had loved, as it is pretended, Socrates loved Alcibiades. ${ }^{13}$

Clearly, Frederick's sexuality was (and remains) a topic that arrests popular and academic attention, and is conspicuous even when absent. But this brings its own problems. For one, the Prussian king was not free simply to do as he pleased. The king derived his power from the Junker class of landed gentry. He was, therefore, to some degree answerable to the Junkers. In this instance, the reality of Frederick's sexuality is irrelevant because, as Zimmermann attests, his homosexuality was accepted almost universally as an established fact. Consequently, given our existing understanding of early modern gender hierarchies and practices, it is striking that Frederick should have had the opportunity to become 'the Great'. Our established model for Prussian masculinity denies Frederick a place in its pantheon, yet his reign remained unchallenged from within for nearly five decades. To understand why this is, we must reconsider how we see Prussian early modern identities as a construct of gender, and the components entailed within those identities.

\section{Sexuality in early modern Germany}

To refer to Frederick as homosexual is fraught with terminological and methodological difficulties. The study of human sexuality has its origins in Germany, but came long after Frederick's death in 1786. Indeed, it was not until the late nineteenth century that the idea of homosexuality, and the terms used to describe it, entered the German parlance.

13 Johann Georg Zimmermann, 'On Frederick's Supposed Grecian Taste in Love', in Johann Georg Zimmermann, Select Views of the Life, Reign, and Character of Frederick the Great, King of Prussia, vol. 1 (London: Hookham \& Carpenter, and E. Newbery, 1792), 45-46. 
The very term 'homosexuality' and its implications were first expostulated by the German-Hungarian doctor, Karl-Maria Kertbeny, in an 1868 pamphlet aimed at decriminalising same-sex relations. ${ }^{14}$ Kertbeny's contemporary, the Bavarian lawyer Karl Heinrich Ulrichs, also campaigned for the normalisation of same-sex relationships. Unlike Kertbeny, who saw homosexuality as a biological imperative, Ulrichs saw his own samesex desires as a deeply ingrained question of identity, significantly more complex than simply, as Kertbeny would understand it in 1868, the act of members of one gender sexually desiring members of the same gender.

According to Ulrichs, a same-sex desiring man was not quite male, but rather was masculine in a superficial sense. The male body was a vehicle for a soul that was female, and the person with a male body but a female soul was neither male nor female, but inhabited a third existence. Ulrichs coined the term 'Uranian' (Urning) to describe this type of person: a 'third sex coordinated between the genders of the male and female'. ${ }^{15}$ Ulrichs' Uranians were not 'women trapped in men's bodies', since this would imply a defiance of a natural order. Ulrichs instead equated Uranians to hermaphrodites. Uranians, he argued, were born with one set of gendered genitalia but the emotional and sexual desires of the other gender. ${ }^{16}$ Kertbeny, who rejected the idea of a female soul but a male body (or vice versa), presented a less complicated concept: men could be born naturally to desire men, and women could be born naturally to desire women. In this sense, both men differed from many of their successors, who viewed homosexuality and same-sex desires as a form of psychosis, adopted either voluntarily or involuntarily.

The scientific and academic study of 'sexuality' was in its infancy in the mid and late nineteenth century, but homosexuality and homosexual behaviour existed, and was observed, long prior to this. In part, samesex desire was understood to be foremost based within the body. Close, same-sex friendships and emotional relationships were not uncommon. Indeed, as Robert Beachy notes, at the end of the nineteenth century the Russian psychologist Marc André Raffalovich argued that homosexual

14 Karl-Maria Kertbeny, '\$143 des Preussischen Strafgesetzbuches vom 14. April 1851 und seine Aufrechterhaltung als $\$ 152$ im Entwurfe eines Strafgesetzbuches für den Norddeutschen Bund’ (Leipzig: 1868).

15 Numa Numantius [Karl Heinrich Ulrichs], Vindex. Sozial-juristische Studien über mannnmännliche Geschlechtsliebe. Erste Schrift über mannmännliche Liebe (Leipzig: Heinrich Matthes, 1864), 5 (emphasis in the original).

16 See also Hubert Kennedy, 'Karl Heinrich Ulrichs: First Theorist of Homosexuality', in Science and Homosexualities, ed. Vernon A Rosario (London: Routledge, 2013), 26-45. 
attachment was a specifically 'German friendship', and while Raffalovich, as a Catholic dividing his time between England and France, aimed to cast aspersions on the Germans with this claim, there was some merit to his methodology. ${ }^{17}$ His citing of the great German romantic authors, poets and playwrights reflects the closeness of their relationships to and with one another, and the homoerotic themes that underpinned much of their work and correspondence.

W Daniel Wilson notes that Goethe's works are conspicuous in their use of homoerotic imagery and so-called 'Greek love'. Rejecting the arguments of Halperin and others that the use of same-sex desire was merely a 'return of affect', Wilson contends that:

neither 'love' nor 'Greek love' are meant 'platonically' or rather unerotically [...] where Goethe claims to speak 'in all purity' of non-sexual relations between men [there are] subliminal allusions and thus [an] irony that playfully undermines [his] own assertions. ${ }^{18}$

Even if Wilson's implications are not conclusive, what is clear is that same-sex desire, platonic or otherwise, was a central, often lighthearted theme in Goethe's oeuvre. The works of his great friend and collaborator, Friedrich Schiller, were no less interpretable as homoerotic. In 1903, his poem Die Freundschaft (The Friendship) was infamously deemed to be homoerotic by the censorship authority of the German Empire, owing to its depiction of kissing between two male friends and the exuberance of a friendship that is 'lovelier than Heaven itself'. ${ }^{19}$

In German literary circles of the mid to late eighteenth century, then, homoerotica and 'Greek love' were hardly unknown, and indeed were encouraged among those circles' practitioners. In general, opprobrium only came later. In another study, Wilson demonstrates that erotic (and particularly homoerotic) poetry was excised from Goethe's body of work. This was mostly conducted during the nineteenth century by a series of private and official censors who, at least partly, wished to 'save' the image of the literary genius from the whiff of sexual scandal. ${ }^{20}$ As noted, Schiller's Die Freundschaft also earned the ire of imperial censors at the turn of the twentieth century.

17 Robert Beachy, 'The German Invention of Homosexuality', The Journal of Modern History 82, no. 4 (2010), 829: doi.org/10.1086/656077.

18 W Daniel Wilson, Goethe Männer Knaben: Ansichten zur 'Homosexualität' (Berlin: Insel, 2012), 35.

19 Robert Beachy, Gay Berlin: Birthplace of a Modern Identity (New York: Vintage, 2014), 108-09.

20 W Daniel Wilson, Goethes Erotica und die Weimarer 'Zensoren' (Weimar: Wehrhahn, 2015), passim. 
This is not to say that same-sex desires were openly condoned prior to the nineteenth century. It is true that they were regulated by law, although generally under the banner of 'sodomy', a charge encompassing sexual acts deemed to be against the natural order, including same-sex liaisons. ${ }^{21}$ In Prussia, the punishment for sodomy was strengthened by Frederick's father, Frederick William I, who made it a capital offence during his reign. This was demonstrated most notably in the 1721 case of Catharina Margarethe Linck, a woman who, presenting as a man, married and had sexual relations with another woman. Upon the personal intervention of the king, Linck was executed. ${ }^{22}$ However, even though the laws appear uncompromising, their application was not. Isabel Hull, for one, notes that sodomy was rarely addressed in official documentation or in reforms to the law and, given that consensual same-sex acts 'usually left no traces [...] to attract official attention', it sufficed for authorities wanting to regulate sexual behaviour to merely 'promise draconian punishment and its occasional execution', rather than energetically attempt to repress it. ${ }^{23}$ Even in the Linck case, learned legal opinion suggested that the defendant should be imprisoned and exiled, overturning the initial decision to have her tortured. It was only with the intervention of Frederick William that capital punishment was enforced. ${ }^{24}$

With regards to the regulation of sex, then, the situation in early modern Germany was less explicit than the law itself would suggest. Yet sex itself is only one aspect of same-sex desire and the construction of self.

21 The Allgemeines Gesetzbuch für die Preußischen Staaten (General State Laws for the Prussian State) (1792), which was ordered by Frederick but completed and enacted after his death, lists 'Sodomiterey' only as an 'unnatural sin'. A more precise definition was offered by the jurist Wiguleus Xaver Alois von Kreittmayr in his codification of Bavarian criminal law, in which the sodomy charge covered 'carnal comingling with an animal, dead bodies, or people of a single sex, as man with man, woman with woman'. Cf Isabel V Hull, Sexuality, State, and Civil Society in Germany, 1700-1815 (Ithaca: Cornell University Press, 1997), 68; Allgemeines Landrecht für die Preußischen Staaten, Zweyther Theil (Berlin: 1794), \$1069.

22 Brigitte Eriksson, 'A Lesbian Execution in Germany, 1721: The Trial Records', Journal of Homosexuality 6, nos 1-2 (1981), 38-40: doi.org/10.1300/J082v06n01_04; Louis Crompton, Homosexuality and Civilisation (Cambridge: Harvard University Press, 2006), 473-475.

23 Hull, Sex, Sexuality, and Civil Society in Germany, 70-1. This should not be taken to mean that authorities did not take sexual 'deviance' seriously, as Hull also cites many efforts by authorities to regulate these affairs. Rather, practical considerations made it difficult or impossible to do.

24 In another study of early modern German justice, Joel F Harrington demonstrates that the Nuremberg travelling executioner, Frantz Schmidt, generally acted with leniency towards those found guilty of sodomy, though the law prescribed their execution. In one particular case, one manwhom Schmidt would have been legally justified in burning at the stake-was instead merely flogged. See Joel F Harrington, The Faithful Executioner: Life and Death, Honour and Shame in the Turbulent Sixteenth Century (New York: Farrer, Straus and Giroux, 2013), 159-61. 


\section{Gender and the Prussian State}

In many ways, homosexuality was initially understood in similar terms to those presented by Ulrichs in 1868. Instead of theorising about Uranians and a third sex, however, those meditating on gender roles chose to situate people who deviated from an established social norm within the grey areas of the defined binary. In other words, gender was not necessarily something that someone was born into and defined by genitalia. Instead, early modern Germans situated themselves within a complex system of honour, virtue and activities—not just sexual—that were considered normative for a certain gender. Ulrich believed that a 'real man possessed a male body and a male sex-love for women', which required that someone (like him) who possessed a 'male body' but 'the female's sex-love for men' had to occupy a different identity (in Ulrich's conception, a Uranian). ${ }^{25}$ By contrast, what German understandings of gender in the century prior to Ulrichs implicitly allowed for was that maleness was neither defined by a penis nor by a sexual desire for women, but was instead defined by a whole collection of behaviours that would cumulatively affect one's identity.

The defining characteristic of the Prussian identity of the early modern and modern period was to be 'male' in a strict sense of the term. In part, this idea of Prussianness was reinforced by the nature of the state itself. Mirabeau was being simplistic — but perhaps not excessively so-when he claimed that 'Prussia is not a state in possession of an army, rather an army that occupies a state'.

This sense of military honour and duty served to enforce a distinct gender divide in Prussian society. In 1815, the government censor Heinrich Renfner complained that too many of the patriotic pamphlets followed a predictable, monotonous trope, appealing 'ad nauseam' to the masculine militarism and the duty of men in times of danger. ${ }^{26}$ Renfner's artistic sensibilities were wounded by the constant repetition in the works he reviewed, but the fact that he made mention of the trend is significant enough, insofar that it demonstrates the ubiquity of Prussian appeals

25 Jonathan Ned Katz, The Invention of Heterosexuality (Chicago: University of Chicago Press, 2007), 51

26 Heinrich Renfner, February 1815, cited in Karen Hagemann, Mannlicher Mut und teutsche Ehre: Nation, Militär und Geschlecht zur Zeit der Antinapoleonischen Kriege Preußens (Paderborn: Ferdinand Schöningh, 2002), 204. 
to manhood, and the relationship between militancy and manliness. Friedrich Ludwig Jahn, the 'father of gymnastics' and national theorist, used his 1810 meditation on the 'German citizenry' to expostulate on the distinction between genders. 'That which emerges from the forces, phenomena and products of nature with strength, power and fertility is male', he told his readers. 'That which is governed by grace, goodness, quiet efficiency and power limited by self-consciousness is of the female sex'. ${ }^{27}$

These ideas, distinguishing the character traits and therefore the roles of men and women in society, were deeply entrenched in traditional ideals of the household, and Prusso-German society as a whole. Indeed, the German historian Karen Hagemann has pioneered a two-pronged concept of German (and, in particular, Prussian) masculinity:

[F]irst, men's readiness to defend family, 'home' (Heimat), and 'fatherland' by force of arms and to die a 'hero's death' on the 'altar of the fatherland'; and second, with the introduction of universal conscription, the linking of masculine 'valour' and political citizenship rights. Only a 'valiant' man was considered a truly German man. ${ }^{28}$

Men were to be strong, powerful and answerable to a higher cause. In this framework, it was not only good but also right to die for the cause that, in turn, treasured these ideals. Thus, when Mirabeau referred to Prussia as an army possessing a state, he had (perhaps inadvertently) defined the kingdom as an arena of hypermasculinity. The army was the place of men, not women, and those men were to be dedicated to making war. But defining gender by behaviours and actions, in turn, introduces a clear component of alterity to a rigid, dichotomous system of attributes.

These Prussian historians take their cues from the nineteenth century, and their models are based on the Prussian bourgeoisie. However, each is clear on the fact that Prussian bourgeois masculinity did not emerge from nothing, but rather coopted the strictures of aristocratic or Junker masculine virtue. As they saw it, the aristocratic class had jettisoned these virtues and adopted more effete and feminine characteristics.

27 Friedrich Ludwig Jahn, Deutsches Volksthum (Leipzig: 1810), 131.

28 Angelika Schaser, 'The Challenge of Gender: National Historiography, Nationalism, and National Identities', in Gendering Modern German History: Rewriting Historiography, ed. Karen Hagemann and Jean H Quataert (New York: Berghahn, 2008), 49. Hagemann's theoretical framework is discussed in depth in Karen Hagemann, 'Tod für das Vaterland: der patriotisch-nationale Heldenkult zur Zeit der Freiheitskriege', Militärgeschichtliche Zeitschrift 60, no. 2 (2001), 307-42: doi.org/10.1524/ mgzs.2001.60.2.307. 
But when had this shift towards 'effeminate' aristocracy occurred? Hagemann places the development during the French Revolutionary and Napoleonic Wars (1792-1815). This is hardly surprising since the early nineteenth century saw the expansion of the middle classes into weighty forces of political and social action, as a result both of the upheavals of the wars, and also because of the effect that increasing industrialisation had on class demographics. ${ }^{29}$ Furthermore, in spite of its place in the victors' circle by 1815, Prussia had experienced defeat and humiliation on a previously unimagined scale, especially during Napoleon's campaigns in central Europe.

This, to the denizens of the burgeoning Prussian middle class, was to be explained, not by the failures of the army, but by the excesses and frivolity of the upper classes. As Martina Kessel explains, men who enjoyed or displayed artistic talent, or who chose to pursue luxury and comfort (or, indeed, displayed a degree of gregariousness such that they might have been termed 'socialites'), found themselves alienated by these social constructs, since these qualities were increasingly defined as feminine. The attempts of such men to portray themselves as 'whole' or 'complete' men was met with limited success within a Prusso-German national model of gender and sex that was so inflexible that it could not accommodate difference. ${ }^{30}$ At the same time, austere middle-class men, who bore the brunt of the wars' impact, were soon fêted as patriotic heroes in spite of an aristocratic leadership that had, in its own cowardice, forsaken them. ${ }^{31}$ In contrast to the men celebrated in art, prose and verse, who fought guerrilla-style operations against the invading French, the royal family had fled to Königsberg. It is telling that Arndt's poem extolling the courageous king of Prussia' implies that the king's courage derived, not from his own kingly soul, but rather from the 'threefold hundred thousand men'mostly of middle-class or lower birth-at his command. ${ }^{32}$

Yet, if these apparently hypermasculine characteristics employed by the bourgeoisie during the wars were a response to an aristocratic shift to what the middle classes viewed as femininity, then it is also clear that they

29 Joyce Appleby, The Relentless Revolution: A History of Capitalism (New York: WW Norton \& Company, 2010), 171.

30 Martina Kessel, "The "Whole Man": The Longing for a Masculine World in Nineteenth-Century Germany', Gender \& History 15 (2003), 1-31: doi.org/10.1111/1468-0424.00287.

31 Karen Hagemann, Revisiting Prussia's Wars against Napoleon: History, Culture and Memory (New York: Cambridge University Press, 2015), 50: doi.org/10.1017/CBO9781139030861.

32 Ernst Moritz Arndt, 'Der tapfere König von Preußen', 1813. 
had been absent in the ruling class for some time. Frederick William III may have been considered sensitive or 'soft', but by these standards his father could have hardly been considered a paragon of masculinity either. Frederick William II, a patron of the arts with an interest in pagan mysticism, had such a predilection for licentiousness that he was nicknamed 'the fat scallywag' by his subjects. Nor, indeed, could the model be applied to Frederick the Great. Frederick's artistic pursuits, as well as his keen interest in horticulture, music and literature, are not easily reconciled with the frugal bourgeois war heroes that came to define Prussian manliness.

Frederick's father, Frederick William I, is a different story. A complex figure, Frederick William embodied the masculinity that, a century later, would be so prized by the middle classes. He was an intensely austere man, who eschewed art in all its forms as dangerous, luxurious distractions that would, if permitted, chip away at a man's moral fortitude. To Frederick William, virtue sprang from piety and strength; as king, his role was to aggrandise Prussia, while at the same time maintaining his rigid morality. That morality could be compromised by cultural pursuits, which he felt opened the soul to temptation. Crucially, the rejection of cultural education was not extended to the women of his household. His wife Sophia Dorothea and daughter Wilhelmina were both warm, gregarious and tender, as well as voracious readers of poetry and prose, and patrons of music and theatre. These, however, were womanly pursuits, and certainly not compatible with the masculine role of the patriarch of the Hohenzollern dynasty. They were also, then, unfit for the crown prince.

And yet, from a very early age, Frederick proved to be contrarian and, alarmingly for his father, far more interested in 'feminine' pursuits. Frederick William's attempts to remove female influences on his son was met with little success. When he returned home from studying at Wüsterhausen, Frederick would often escape his formal lessons, choosing to hide among his mother and sister in their salon, reading French poetry with them. He cowered at gunfire, and preferred to spend time practising music, eventually becoming a skilled flautist. ${ }^{33}$ In particular, Frederick's father was enraged by his son's interest in French philosophy and literature-none of which he included in the crown prince's curriculumas he considered France to be a country of debauchery and liberal excesses, 
and everything that it produced to be tainted by immorality. ${ }^{34}$ As a result, Prussia under Frederick William had a 'special character' within Europe, in which the 'primacy of utilitarian considerations' promoted an 'official ethic of parsimony and frugality', ${ }^{35}$ much as it would once again return to after (and, to some extent, during) the Napoleonic Wars, under the guidance of the bourgeoisie.

It is implicit in the understanding of this 'return' and 'adoption' principle that Frederick William I's ideal of Prussian masculinity was not completely undermined by his son. Frederick the Great, with his artistic bent and his love of Francophone refinement, is a point of departure from the norm. Indeed, it is tempting to suggest that it is Frederick who began the deviation from utilitarian, pious and dour masculinity towards a more effete aristocracy, thereby creating a gendered vacuum into which the middle classes would step into in the nineteenth century. Seductive as this logic may be, however, it suffers from significant conceptual flaws.

The first is a matter of practicality. Frederick the Great's reign lasted for more than four decades. If, indeed, he characterised a gender shift in which the crown departed from its austere masculine virtue and steered towards the effete, are we then to assume that all of the Junkers followed a similar trajectory at the same time? We must remember that Frederick not only derived his power from the Junkers, but he was also expected to exemplify the highest of Junker virtues. In other words, the virtuous mould already existed, as defined by class rather than by the king. It might certainly have been within the powers of the king to alter that mould according to his own desires, but Frederick's abrupt departure from the example of his father would suggest a complete breaking of the mould, a seismic shift in Junker identity that could not unilaterally be accomplished by the will of the monarch alone. So, how could the Junkers have countenanced a king who presumably did not embody their will and virtue?

34 Frederick William's hatred of the French is attested to by Mitford, who includes an anecdote of condemned prisoners being ordered to dress in French fashion 'in order to give people a horror of such fashions'. Frederick himself was often humiliated by his father's public denouncement of his 'effeminacy'. See Mitford, Frederick the Great, 4-5; and Peter Loewenberg, 'Psychohistorical Perspectives on Modern German History', The Journal of Modern History 47, no. 2 (1975), 234: doi.org/10.1086/241319.

35 Richard L Gawthrop, Pietism and the Making of Eighteenth-Century Prussia (Cambridge: Cambridge University Press, 1993), 1. 
The second fault arising from the logic supposing that Frederick constituted a break in Prussian masculine continuity engages with this latter presumption. However evident it is that nineteenth-century bourgeois actors looked upon Frederick William I as an exemplar of masculinity, it is equally clear that he was not the exemplar for the Junkers of his (rather than the later) Prussia. If, indeed, Frederick William I's successors-and, in particular, his son Frederick-deviated from the masculine norm that he embodied, then it must also be recognised that Frederick William I himself deviated from the norms and behaviours of his father, Frederick I, the first king in Prussia.

Frederick the Great himself demonstrates this in his collected works. 'The state almost completely changed under Frederick William', he wrote. 'Under Frederick I, Berlin was a northern Athens, [but] under Frederick William she became Sparta'. ${ }^{36}$ Moreover, Frederick I's charactercontaining, as it did, tendencies towards artistry, a love of gardening and a consuming passion for music and literature-had more in common with that of his grandson, Frederick the Great, than it did with his son, Frederick William. If there is any constant definition of Prussian masculine character, it is that which binds the two Fredericks, rather than that of the interregnum Frederick William.

\section{Masculinity and the Hausväterliteratur}

It goes without saying that the Prussian king of the eighteenth century was not answerable to the middle class, not least because that class was at best embryonic. The crown's power did not derive from the bourgeoisie, and the king was not expected to embody middle-class values. He was, however, expected to reflect the values of the highest class: the landed gentry, or Junkers.

Values and ethics are rarely static and immutable, and certainly such things were rarely left to chance. Codes of behaviour and morality have existed since ancient times, in the tradition of the oikos (or house texts) of the Aristotelian style. In Germany, texts of this sort were printed throughout the early modern period, beginning at least as early as the

36 Frederick II, 'Mémoires pour servir a l'Histoire de la Maison de Brandebourg', in Euvres de Frédéric le Grand, vol. 1, ed. R Decker (Berlin: Imprimerie Royale, 1846), 266. 
sixteenth century, and continuing through into the eighteenth. ${ }^{37}$ These texts belonged to the categories of Hausväterliteratur (house fathers' literature) and Jagdliteratur (hunting literature). The latter, as the name suggests, offered guidelines for the successful hunting of various types of game-invaluable skills for a landsman to possess in times when hunting remained the primary means of sustenance. The former was rather more expansive. In essence, these works provided instructions for the successful governing and operation of the household. If a man were to master the art of the household Ökonomik (economy), he would represent the ideal 'house father' (Hausvater).

These guidebooks of governing principles were not unique to Prussia and, in general, were published in the great publishing cities of the German region, such as Leipzig, Cologne, Mainz and Nuremberg, rather than exclusively in Berlin or Potsdam. Johann Coler's Oeconomia ruralis et domestica was printed in Mainz in 1645, and enjoyed reprints well into the eighteenth century. Coler's work, as suggested by the title, emphasised the importance of governing both rural and domestic affairs, and its advice-spanning close to 1,000 pages-covered such esoterica as the correct ways to serve beer to visitors and the spicing of cabbage to ensure its preservation over winter. Franz Philipp Florin's Oeconomia prudens et legalis, published 11 years after Frederick the Great took to the Prussian throne, enjoyed a print run in the largely autonomous city of Nuremberg, the imperial city of Frankfurt am Main, and the Saxon town of Leipzig. ${ }^{38}$ These works largely covered the practicalities of governing a noble household; Wolf Helmhard von Hohberg's 1682 manual, Georgica curiosa aucta, subtitled Adeliches Land-und Feld-Leben ('Noble Land- and Field-Life'), built on Coler's example by imbibing the pragmatic rules with spiritual and moralistic elements. Like many of the Hausväterbücher, Hohberg's work outlived him-an 'expanded and improved' edition appeared as late as $1716 .{ }^{39}$

The German term Ökonomik itself derived from the Greek oikos. Otto Brunner has noted that early modern Hausväterliteratur was:

37 Maike-Franziska van Haag, Recht in der Hausväterliteratur: Der 'Oeconomus Prudens et Legalis' vom Franz Philipp Florin im Kontext seiner Zeit (Berlin: Lit-Verlag, 2014), 1.

38 Johann Coler, Oeconomia ruralis et domestica (Mainz: Churfürstlich. Mayntzischer Hoff- und Universitet Buchtrucker, 1645); Franz Philipp Florin, Oeconomia prudens et legalis (Nuremberg, Frankfurt and Leipzig: Christoph Riegel, 1751).

39 Wolf Helmhard von Hohberg, Georgica curiosa aucta (Nuremberg: Martin Endter, 1716). 
Ökonomik in the older sense [that is to say, oikos] and thus contained an abundance of ethical, sociological, pedagogical, medical, [and] agronomical material, which is not simply a collection of individual pieces of knowledge, but rather is held together through the orderly principle of the household via the decisive leading function of the man of the house. ${ }^{40}$

The characteristic ideals of manhood and masculinity found within the pages of a disparate selection of Hausväterliteratur manuals, across borders both physical and temporal, have remarkable consistency. And it is notable that the authors and publishers found audiences elsewhere. The Saxon jurist Julius Bernhard von Rohr, for example, wrote extensively on the issue of masculine honour and education, which he felt was a universally German preoccupation. At least one of his books_Einleitung zur CeremonielWissenschafft der Privat-Personen (1728)—was published in Berlin, and conspicuously aimed at a readership of 'young German cavaliers. ${ }^{41}$

It was in these texts that masculinity for the landed gentry was defined, and it is this definition to which the Prussian king was expected to adhere. The very name of the collected works - the 'house fathers' literature'betrays their emphasis on masculinity, though this is often couched in terms of 'blood' or hereditary genealogy (which, in any event, were construed as traits and lineages passed down through masculine lines). ${ }^{42}$ To modern eyes, the characteristics that defined masculinity appear somewhat eclectic. Hohberg's Georgica curiosa provides one of the most comprehensive collections of noble guidelines. The work is divided into two parts, which combine the genres of Hausväter- and Jagdliteratur; the first part covers the role of the house father within the household, as well as his place in society, while the second presents instructions for hunting game and raising livestock. These are, in turn, divided into separate books of themes within these categories. Part one-of most use to us here-provides explicit guidance on the delineated roles of men. Topics covered include good business practices and fiscal responsibility (Buch I), wholesome relationships with family and community (Buch II), delineating the role of the wife or Hausmutter (Buch III), the growing of vineyards and orchards (Buch $I V$ and Buch $V$ ), and the aesthetic organisation of horticultural gardens (Buch $V I)$.

40 Otto Brunner, 'Hausväterliteratur', in Handwörterbuch der Sozialwissenschaften, vol. v (Stuttgart: G. Fischer, 1956), 93. Cf van Haag, Recht in der Hausväterliteratur, 43ff.

41 Julius Bernhard von Rohr, Einleitung zur Ceremoniel-Wissenschafft der Privat-Personen (Berlin: Johann Andreas Rüdiger, 1728).

42 William D Godsey Jr, 'Nobles and Modernity', German History 20, no. 4 (2002), 513. 
This expansive series gives some indication of the complex roles and characteristics expected of aristocratic men. The responsibilities of noblemen towards women, and their relationships with them, comprises very little of the work, with Hohberg concluding that " $t$ ] he lordship of man over woman is precisely a small reflection of God's lordship over humanity ${ }^{43}$ In his meditation on the role of the Hausmutter, however, Hohberg softens his stance. A household without a woman, he laments, would be 'like a day without sunshine, a garden without flowers, or water without fish'. This has little to do with the natural gender order, Hohberg insists, except for the fact that the relief a man would feel upon returning home to a 'faithful and loving woman' would help to keep household affairs in order. ${ }^{44}$

Beyond this the Georgica curiosa is largely silent; its aim is to define the role that men and women play within an extant, marital relationship, rather than situating that relationship at the centre of a masculine or feminine character. In fact, of the five books that make up the Hausväterliteratur component of the Georgica curiosa, it is essentially only the second book that addresses the question of romantic relationships, and then only in passing. Even here, though, women are seen as a contingency. Hohberg sees the role of the Hausmutter as being analogous to the Hausarzt (house doctor); nevertheless, skills in medicine (including medicinal botany) are among the requirements for the Hausvater as well. This reflects Coler's meditations on masculinity from 1645, in which he insists that an accomplished Hausvater must be well versed in experimental pharmacology, in order to maintain the health and wellbeing of his household. ${ }^{45}$ The role of the woman, therefore, is ancillary to that of the man. Her duty is to provide care for a situation in which the Hausvater could not himself provide it. At no point is it suggested that the Hausmutter could demonstrate qualities of house leadership; her role is simply to make sure that the Hausvater is capable of fulfilling his. In any event, Hohberg's attention is soon drawn towards matters of how good Junker men should conduct themselves while travelling, or whether or not a Hausvater should allow his sons to study abroad.

43 Hohberg, Georgica curiosa aucta, 142-43.

44 Hohberg, Georgica curiosa aucta, 273.

45 Hohberg, Georgica curiosa aucta, 335-454; Coler, Oeconomia ruralis et domestica, 72-281. 
The role and responsibility of women in this 'manual of masculinity', then, is somewhat elusive, and any discussion of the actual mechanics of sexual relations is absent. Hohberg should not be considered prudish or remiss in this regard, as similar absences are to be noted in other, comparable texts already mentioned. And yet, in conceptualising other aspects of Junker masculinity, Hohberg is loquacious and occasionally employs a thoughtful degree of wit to illustrate his points. The son of a noble house, he insists, can only hope to rise higher in his station through strength of character and intellect, noting that:

he must have a brave, steadfast, but in this also a prudent, patient disposition, must before this be well-versed in studies and in travel, but where these traits are not in evidence, he should at least not be an idiot. ${ }^{46}$

As crown prince, Frederick was often the target of his father's ire, owing largely to his interest in reading and education. These were, to Frederick William, not occupations befitting the man who would eventually succeed him to the Prussian throne. However, intellect was highly prized by the Junkers and the authors of the Hausväterbücher, from which they took their social and cultural cues. This can be seen not only in the works themselveswhich list, among those good skills that should be possessed by a wellrounded Junker male, a familiarity with poetry, music, literature and the aesthetics of horticulture-but also in the typical education of a Junker.

Jan Peters' account of the everyday life of the Junkers of PlattenburgWilsnack provides some insight into the nature and role of education in the 'creation' of an exemplar of Prussian noble life. Here, Peters uses the example of Frederick August von Saldern, who would become a court adviser to Frederick William. Saldern, born in 1694, was educated at home under a 'strict homeschooling regime' until he turned 10. From that point, he attended a 'noble school' (Adelsschule) in Berlin, and a year later, he began attending university in Halle an der Saale, from where he graduated in 1711 . Throughout these years of education, he followed a typical subject trajectory of a 'Junker and cavalier', studying mathematics, history, geography, law, Latin, Greek, French, drawing, fencing, dancing and piano. ${ }^{47}$ Similar intensive learning regimes had been

46 Hohberg, Georgica curiosa aucta, 156. Emphasis in original.

47 Jan Peters, Märkische Lebenswelten: Gesellschaftsgeschichte der Herrschaft Plattenburg-Wilsnack,

Prignitz 1550-1800 (Berlin: Berliner Wissenschafts-Verlag, 2007), 674. 
the norm for the aristocrats of the houses of Plattenburg and Wilsnack, and indeed elsewhere in Brandenburg-Prussia, since at least the sixteenth century.

The origins of this schooling regime hint at why so many lessons were taught in such a short space of time; the eldest son of a noble family had to be prepared to assume his role as the head of the house as soon as possible, especially in an era when mortality rates were higher and life expectancies unpredictable. But the emphasis of this education was fundamentally grounded in the humanistic virtues of wider knowledge and sensibilities. Given the limited time in which a Junker male was expected to be educated, it is significant that considerable effort was devoted not just to 'practical' subjects such as mathematics, but also to more ethereal pursuits, such as art, music and the languages of Sappho, Virgil and Catullus. These expectations had longstanding precedents. In England of the sixteenth century, for example, Henry VII had insisted on expansive education for his sons, Arthur and Henry. Those ideals instilled in the princes by Erasmus, André, Skelton and Mountjoy became integral aspects to the Tudor form of cultural chivalric revival that would, in turn, become guiding principles of English aristocratic masculinity well into the age of Byron. ${ }^{48}$

The ruling class of the Hohenzollern Kingdom of Prussia followed similar behavioural guidance. To be a Junker male, and to epitomise the characteristics of the Junker male, was to be well rounded, educated and well read. Such characteristics were laid out in exquisite detail in the Hausväterliteratur. In these strictures, the nature of one's sexuality had a secondary role to that of one's learned character, and one's ability to express cultural and educational refinement. Far from the nineteenthcentury middle-class ideals of frugality and pious austerity, the social and cultural environment in which the Hohenzollern dynasty existed not only encouraged, but required a man to embody 'sensitive' traits that later generations would come to view as 'effeminate'.

48 David R Carlson, 'Royal Tutors in the Reign of Henry VII', The Sixteenth Century Journal 22, no. 2 (Summer 1991), 253-79: doi.org/10.2307/2542735. 


\section{Frederick the Great as an exemplar of Prussian masculinity}

'The World never perhaps beheld a father and son who less resembled each other than these two Monarchs', Voltaire wrote of Frederick William and Frederick the Great. ${ }^{49}$ In many ways, it was Voltaire himself who was responsible (at least in part) for many of the differences between father and son. Frederick's correspondence with the French philosopher and novelist began in 1736, four years before the death of Frederick William, and some 14 years before Voltaire would come to live at Sanssouci. But Frederick's love of Voltaire's works reflected the deeper, innate sense of culture and refinement that was an integral part of the Junkers' sense of masculinity. Frederick praised Voltaire's 'treasures of the mind, and pieces of workmanship laboured with so much taste, delicacy, and art, that their beauties appear new every time they are examined'. ${ }^{50}$ It was precisely the qualities of 'taste, delicacy, and art', and the identification and appreciation of them, that was central to Junker education, through schooling as well as the Hausväterliteratur.

Ironically, this education had been denied to Frederick by his father, who saw no practical use for poetry, music or aesthetics. It was left to the crown prince to educate himself through the works of philosophers like Voltaire. Yet the fact that Frederick had not been formally educated in philosophy, literature and art was the exception rather than the rule; if Frederick William saw these pursuits as 'effeminate' and 'womanly', then it is a reflection more on the father and his unique mentality, rather than on Prussian society. Frederick seemed to recognise this in his claim that his father's Prussia was like Sparta to Frederick I's Prussian Athens. Not only did this suggest a turn towards militarism, but it also suggested a shift away from the enlightened, artistic, 'Athenian' values of the earlier Prussia. Voltaire used similar imagery in his memoirs, comparing the shift in governance to Frederick William as akin to the sack of Rome. In one passage, he beseeches his reader to imagine Frederick's difficult childhood:

We may easily imagine, what would be the astonishment of a Vandal like this, to find he had a son endowed with wit, grace, and good breeding; who delighted to please, was eager in the acquisition of knowledge, and

49 Voltaire, Memoirs of the Life of Voltaire, Written by Himself (Dublin: Moncrieffe, Walker, Exshaw, Wilson, Jenkin, Burton, White, Byrne, Marchbank, Cash and Heery, 1784), 11.

50 Frederick II to Voltaire, Berlin, 8 August 1736, in Letters, 1. 
who made verses, and afterward set them to music. If he [Frederick William] caught him [Frederick II] with a book in his hand, he threw it in the fire; or playing on the flute, he broke his instrument; and sometimes treated his Royal Highness, as he treated the ladies and the preachers when he met with them on the parade..$^{51}$

Frederick William's behaviour towards his son was notable in its departure from the norms. This set Frederick William apart from his forebears, from the pattern that would be adopted by his son and successors and, indeed, from the Junker class.

When Frederick William took to the throne upon the death of his father, the chief of the army, Lieutenant-General von Tettau, famously warned the members of the Junkers' privy council: 'Gentlemen! Our good Lord is dead, and the new king will send you all to the devil!'52 Frederick William did away with much of the privilege and pomp of court life-even selling 'all the magnificent furniture left by his father', much to Voltaire's anguish — and, in doing so, undermined the traditional Junker masculine ideal by discrediting it. Where once artistry had been encouraged and welcomed in Prussia, it was now repressed.

To some, Frederick William's disdain for sensibility was so strong that they considered it potentially dangerous. When, in 1737 , a story appeared in the Parisian newspapers claiming that Voltaire was planning to visit the Prussian crown prince, Voltaire was quick to assure Frederick that, while he did indeed hope to make his acquaintance one day, this could hardly happen while Frederick William was on the throne. To arrive without invitation in Berlin, Voltaire recognised, would be courting danger. Such an invitation was not about to come from the king of Prussia (who clearly would have despised Voltaire and all he represented), nor his son (who knew full well the risks of defying the 'brute', Frederick William). ${ }^{53}$ Indeed, the king's testament, written in 1722 and intended to be provided to his heir upon his death, demonstrated the degree to which he expected Frederick to follow in his stead. 'My dear Successor', he wrote (in poorly punctuated, phonetic prose):

51 Voltaire, Memoirs, 20-21.

52 Linda Brüggemann, Herrschaft und Tod in der Frühen Neuzeit: Das Sterbe-und Begräbniszeremoniell preußischer Herrscher vom Großen Kurfürsten bis zu Friedrich Wilhelm II. (1688-1797) (Munich: Herbert Utz Verlag, 2015), 150. See also Heinz Ohff, Preußens Könige (Munich: Piper Verlag, 2009), 45.

53 Voltaire to Frederick II, March 1737, in Letters, 78. 
be well assured that all happy Regents have God before their eyes and have no Mistresses or as is better to call them Whores and who lead a godly life then these regents will be protected by God with all worldly and spiritual blessing as I ask My dear Successor to live a Godly Pure life and to lead a good Transition and to approach his Land and Army with a good example not Drink and gorge from which an obscene life derives, My dear Successor must also not admit any Comedies Operas Ballets Masquerades Balls to be held in his Lands and Provinces and have an abhorrence of them for it is Godless and Devilish for Satan his temple and empire are increased [by them]. ${ }^{54}$

Frederick William's antipathy towards the creative arts was made explicit in his description of them as 'Godless and Devilish'. Equally clear was the fact that Frederick would not follow this template. Once the king had died, his son toured the streets of Berlin in an open-top carriage, promising reforms based upon Enlightenment intellectualism even as he had coins strewn along his way for the excited crowds to collect. ${ }^{55}$ But this was a restorative transformation, resurrecting older traditions. Within months, Frederick would be working actively to transform his court at Potsdam into a beacon of European Enlightenment. His desire to do so would attract many of the greatest contemporary minds. Musically, Frederick's retinue of court musicians expanded until late into his reign, and included many of the highest-regarded composers and artists of the age, including Karl Heinrich Graun, Johann Frederick Agricola, Johann Joachim Quantz and CPE Bach. He took to his flute with gusto, producing no fewer than 121 concertos. ${ }^{56}$ In 1779, as his health began to fail, he despaired that his inability to play it regularly was akin to losing his 'best friend'. 57

54 Reproduced in Die politischen Testamente der Hohenzollern nebst ergänzenden Aktenstücken, vol. I: Die Hofordnung Joachims II., die politischen Testamente des Grossen Kurfürsten von 1667 und Friedrich Wilhelms I. von 1722, ed. Georg Küntzel and Martin Haas (Leipzig and Berlin: B.G. Teubner, 1911), 71. 55 On the remarkable differentiation between Frederick William and Frederick's approach to governance, and their conceptions of virtue in general, Christopher Clark usefully notes that the Hohenzollerns after the Thirty Years War seemed to embody a strange synthesis of leadership, in which the goals and development of the state seemed to follow seamlessly between successors, while their actual individual approaches to power demonstrated rupture between father and son. That of Frederick William and Frederick was, by this stage, only the latest in a series of such fraught relationships. See Christopher Clark, Iron Kingdom: The Rise and Downfall of Prussia 1600-1947 (London: Penguin, 2007), 101.

56 Ernest Eugene Helm, Music at the Court of Frederick the Great (Norman, Oklahoma: University of Oklahoma Press, 1960), 41-42.

57 Warwick Lister, Amico: The Life of Giovanni Battista Viotti (Oxford: Oxford University Press, 2009), 49: doi.org/10.1093/acprof:oso/9780195372403.001.0001. 
But he also maintained his adolescent love of literature and poetry, and Voltaire's tenure at Potsdam, between 1750 and 1753, demonstrated Frederick's devotion not only to improving his own literary output, but also to benefitting from the profound influence of one of the French Enlightenment's most prominent thinkers, and the author of 'letters and verses, superior in beauty to every thing which has ever appeared' ${ }^{58}$ When Voltaire finally came to Potsdam in 1750 it seemed that Frederick had successfully repositioned Prussia as a centre of enlightened liberalism. Frederick William's Prussia had disgusted Voltaire-'Turkey, it must be confessed is a Republic, when compared to the despotism exercised by this Frederic-William'59 — but in Frederick's kingdom he found wonderment. '[Potsdam] is the paradise of philosophers', he wrote to his friend, the marquis de Thibouville, shortly after arriving.

It is beyond all expression. It is Caesar, it is Marcus Aurelius, it is Julian, it is sometimes the abbé of Chaulieu with whom one sups. It is the charm of retirement, the ease of country life, with all the little comforts. ${ }^{60}$

Such a thing would never have been tolerated under Frederick's father, and yet it was vital to Frederick's own sense of self-his remedial education on how to be a Junker male, so to speak-that he did so. And, if the king was to embody the masculine strictures of the Hausväterliteratur, then Frederick's Potsdam court of 1750, his 'paradise of philosophers', had been transformed to incorporate the expression of those strictures: mastery of art, music, letters and philosophy.

Just 10 years after the death of 'the Vandal' Frederick William, Voltaire was happy to report that Potsdam was filled with

a hundred and fifty thousand victorious soldiers [but also] opera, comedy, philosophy, poetry [...] grandeur and grace, grenadiers and muses, trumpets and violins, society and freedom! Who would believe it? And yet it is all too true. ${ }^{61}$

Voltaire may just as well have been reading from section headings from the various Oeconomia, Georgica curiosa, or Rohr's Ceremoniel-Wissenschaft. In this case, Voltaire's description of Frederick-'a philosophical hero who is also a poet'-is perhaps one of the most accurate summaries of

58 Frederick II to Voltaire, Remusberg, 9 November 1738, in Letters, 417.

59 Voltaire, Memoirs, 16.

60 Voltaire to Henri-Lambert d'Herbigny, marquis de Thibouville, Potsdam, 24 October 1750, in Letters.

61 Ian Davidson, Voltaire: A Life (London: Profile, 2010), 245. 
a character most closely adhering to the demands of the Hausväterliteratur and, thus, the character most demonstrating the Prussian gentry's sense of masculinity in the eighteenth century.

\section{Conclusion}

Ever since his death, Frederick the Great has caused his biographers and historians no small amount of difficulty in defining him, his existence and his place in Prussian society. To some extent this was true even during his reign. Voltaire, who had been so enthused by Prussia's return to and expansion of 'society and freedom', soon became disenchanted by what he saw as irreconcilable contradictions. His modern Athens still contained a core of Sparta, and Frederick's ability to make war, however reluctantly, grated at the Frenchman's sensibilities. But Voltaire was expecting too much from Frederick, for Prussia could never break away from its deeply ingrained militaristic qualities. Indeed, Frederick's reforms, and the transformation of Potsdam and Berlin into jewels of Enlightenment civilisation, merely fuelled the need to defend what the Hohenzollern crown held. That militant ideal had always existed and would continue to exist whether Frederick wrote poems and played his flute or not.

Voltaire's departure under a cloud of ill-will in 1753 had significant implications for the way Frederick has been remembered. Not long after departing, a book entitled The Private Life of the King of Prussia appeared, first in Paris and Dresden, and then elsewhere. Purporting to be a tellall exposé of the king's more unorthodox predilections, The Private Life gave graphic descriptions of Frederick indiscreetly picking from a string of male lovers. It was from this text that European readers not only came to believe that Frederick had homosexual desires, but that he was the 'passive partner' in sexual encounters with men. The writing style bore a striking resemblance to that of Voltaire and, whether or not it was indeed the Frenchman who wrote the text, it soon became widely accepted that only Voltaire would have had such detailed knowledge of the king's sex life. ${ }^{62}$ Other rumours followed. Even after Frederick and Voltaire had mended fences, the latter's memoirs still included references to Frederick's sexual tastes. Others followed suit: Goethe's private art collection included, among other pieces, a sketch of Frederick (identifiable by his ubiquitous

62 Voltaire, Das Privatleben des Königs von Preußen, oder Nachrichten zum Leben des Herrn von Voltaire (Leipzig: Kummer, 1784), 50-51. 
three-cornered hat) engaged in anal intercourse with the Greek fertility god, Priapus (also easily identifiable, in this case due to his oversized erection). ${ }^{63}$

Zimmermann was justified in 1786 to claim that all of Europe believed that Frederick was a 'socratic lover'. But in spite of this knowledge, Frederick's fitness to govern never appeared to have been threatened. This suggests that the governing principles of the king's masculinity, as dictated through the Hausväterliteratur and the adopted cultural gender norms of the Junkers', were not impinged upon by the king engaging in homosexual sex-passively or otherwise. What could impinge on that masculinity was an inability to employ the skills expected of a man well versed in humanistic education and qualities. In this, Frederick might have been at a disadvantage due to his limited formal education, but he overcome any gaps in his education with his own curiosity and drive.

Nine years after taking the throne and writing La Jouissance, Frederick wrote another poem. This one, also addressed to the Swan of Padua, bares striking familiarity to that which MacDonogh and others identified in the 1740 verse:

Devoted courtier of the beautiful god of Cythera,

Of taste, of grace and of wit:

Algarotti, who knows to please

The beautiful, the learned, all kinds of spirits:

From where does this illness come that the doctor,

By flattery, somehow causes?

I, who am not so learned, I think the disease

Makes you restless and dreamy,

Instead of attacking your life,

Only attaches to your heart.

Yes, this fever which burns

During the night, during the day,

Appears to my incredulous eye

To be some evil called love.

I am more inflamed by this evil than you!

Where would your talents, so clever and so able, take you to find the remedy?

63 Wilson, Goethe Männer Knaben, 101. A reproduction of the sketch is shown in fig. 4 of the same. 64 Frederick II, 'Au Comte Algarotti', Potsdam, 25 September 1749, in Euvres de Frédéric le Grand, volume 18, ed. R Decker (Berlin: Imprimerie Royale, 1851), 79. 
What is remarkable about this poem, as well as La Jouissance and others like them, is not necessarily their content. Frederick's love for men (presumed or real) had no bearing on his leadership, because it was not considered to have a decisive impact on his manliness. Instead, the very fact that he committed these feelings to paper, in verse, demonstrated his accomplishment as an intelligent, educated and urbane man of the ruling class. Whatever Macaulay may have thought of Frederick's poetry, it remains one of many aspects of a personality that would mark him, in the eyes of his subjects, as a great man. 
This text is taken from ANU Historical Journal II: Number 1, published 2019 by ANU Press, The Australian National University, Canberra, Australia.

doi.org/10.22459/ANUHJII.2019.11 